\title{
Association between New Platelet Indices and Calcific Aortic Stenosis: Plateletcrit and Platelet to Lymphocyte Ratio
}

\author{
Yeni Platelet Belirteçleri ve Kalsifik Aort Darlığı Arasındaki İlişki: Plateletkrit ve \\ Platelet Lenfosit Oranı
}

\author{
Hüseyin Altuğ Çakmak ${ }^{1, *}$, Asım Enhoş ${ }^{1}$, Mehmet Ertürk ${ }^{2}$, Ali Kemal Kalkan ${ }^{2}$, Muhammet Hulusi \\ Satılmışoğlư ${ }^{2}$, Mehmet Gül ${ }^{2}$
}

${ }^{1}$ Mustafa Kemalpasa State Hospital, Department of Cardiology, Bursa, Turkey

${ }^{2}$ Mehmet Akif Ersoy Thoracic and Cardiovascular Surgery Training and Research Hospital, Department of Cardiology, Istanbul, Turkey

\begin{abstract}
Objective: Calcific aortic stenosis (AS) is the leading cause of death from valvular heart disease in worldwide. We aimed to evaluate the relationship between plateletcrit (PCT), platelet to lymphocyte ratio (PLR) and presence and severity of the calcific AS in the present study.

Materials and Methods: A total of 98 consecutive patients diagnosed with calcific AS and 30 healthy controls were included in this retrospective study. Patients with calcific AS were divided into three groups according to severity of disease as follows: mild AS $(n=35)$, moderate AS $(n=30)$ and severe AS $(n=33)$.

Results: PCT and PLR were demonstrated to be significantly higher in the AS. Moreover, PCT and PLR were significantly highest in the severe AS group than in the mild and moderate AS groups. Correlation analysis indicated positive significant relationships between the PCT and maximal and mean transaortic gradients, and maximum jet velocities; but negative association with AVA. The same relations were obtained between PLR and echocardiographic parameters of severity of AS.

Conclusion: PCT and PLR, which reflect elevated inflammatory status and platelet activation and aggregation, are useful, cheap, easily available and simply calculated markers that have an ability to improve risk stratification of patients with calcific AS for treatment strategies.
\end{abstract}

Key Words: Plateletcrit, platelet to lymhocyte ratio, calcific aortic stenosis, echocardiography

\section{Introduction}

Calcific aortic stenosis (AS), which is the worldwide leading cause of death from valvular heart disease, is the most common indication for

\begin{abstract}
ÖZET
Amaç: Kalsifik aort darllğı (AD) dünyada kalp kapak hastalıklarından ölümlerin önde gelen nedenidir. Biz bu çalışmada plateletkrit (PKT) ve platelet lenfosit oranı (PLO) ile kalsifik AD'nın varlığ1 ve şiddeti ile olan ilişkisini incelemeyi amaçladık.

Gereç ve Yöntem: Bu retrospektif çalışmaya sırasıyla 98 kalsifik AD tanısı olan hasta ile 30 sağlıklı kontrol dahil edildi. Kalsifik AD hastaları hastalığın şiddetine göre 3 gruba şu şekilde ayrıldı: hafif AD $(n=35)$, orta AD $(n=30)$ ve ileri $A D(n=33)$.

Bulgular: PKT ve PLO aort darllğ1 grubunda anlamlı derecede yüksek bulundu. Ayrıca, PKT ve PLO ileri AD grubunda hafif ve orta AD gruplarına göre önemli derecede en yüksek saptandi. Korelasyon analizinde PKT ile maksimum ve ortalama transaortik gradyan ve maksimum jet akım hızı arasında önemli pozitif, aort kapak alanı ile anlamlı negatif ilişki saptandı. Benzer ilişkiler PLO ile AD şiddetinin ekokardiyografik parametreleri ile gösterildi.

Sonuç: Artmış inflamatuar durum ve platelet aktivasyon ve agregasyonunu yansitan PKT ve PLO kalsifik AD olan hastalarda tedavi stratejileri için risk sınıflamasını iyileştirebilen kullanışlı, kolay elde edilebilen, ucuz ve basit hesaplanabilir belirteçlerdir.
\end{abstract}

Anahtar Kelimeler: Plateletkrit, platelet lenfosit oran1, kalsifik aort darlığı, ekokardiyografi

aortic valve replacement. The prevalence of AS has been reported as 3\% in general population, which has also seen more commonly aged over 75 years (1). Age, gender, hypertension, smoking, hyperlipidemia were presented as independent 
significant risk factors for calcific AS $(1,2)$. Increased platelet activation and aggregation due to raised shear stress in turbulent jet flow of AS were demonstrated in previous studies (3-4). Moreover, polisitemia vera has been reported as a possible cause of AS, which has not been related to severity of disease (5).

Plateletcrit (PCT), which is defined as platelet count x mean platelet volume $/ 10^{7}$, is an indicator of total platelet mass. It is a part of the routine complete blood count (6). The associations and long term prognostic value of PCT have been reported in stable coronary artery disease (7), STsegment (STEMI) (8) and non-ST segment elevation myocardial infarction (NSTEMI) (6), cardiac syndrome X (9). Moreover, clinical utility of PCT has been reported in both coronary slow flow phenomenon and saphenous vein graft disease $(10,11)$.

Platelet to lymphocyte ratio (PLR) is defined as the ratio of the platelet to lymphocyte count obtained from the same blood sample (12). It has also been presented both as new inflammatory marker and a significant independent predictor of long-term prognosis in acute myocardial infarction (12) and peripheral arterial occlusive disease (13). Elevated PLR was demonstrated to be related with severity and complexity of coronary artery disease (14), coronary slow flow (15), poor coronary collateral development (16) in recent studies.

Since there is no information in the literature in terms of relation between PCT and calcific aortic stenosis and only one study has reported a significant independent association of increased PLR with presence and severity of calcific AS (17), we aimed to evaluate the relationship between both PCT and PLR and presence and severity of the calcific AS in the present study. We hypothesized that increased PCT and PLR, which are new indicators of severe chronic inflammation and platelet activity and aggregability, were related with the presence and severity of calcific AS.

\section{Material and Methods}

Ninety-eight consecutive patients, who admitted to outpatient cardiology clinic of state hospital with dyspnea, chest pain and/or syncope and diagnosed with calcific AS by using 2-D transthoracic echocardiographic examination between September 2013 and May 2015, and 30 healthy controls were included in this retrospective case-control study. Patients with calcific AS were divided into three groups according to severity of disease as follows: mild AS $(n=35)$, moderate AS $(n=30)$ and severe AS $(\mathrm{n}=33)$. The demographic, clinical and laboratory characteristics of the patients and controls groups were obtained from hospital records of the participants.

Presence of rheumatic or congenital AS, coronary artery disease, heart failure, peripheral artery disease, atrial fibrillation, congenital heart disease, myo-pericarditis, acute or chronic renal or hepatic dysfunction, concomittant moderate-severe valvular heart disease, acute coronary syndrome, malignancy, presence of prosthetic heart valve, primary or secondary hyperparathyroidism, acute or chronic infectious / inflammatory disease and use of medical therapy affecting platelet count or functions were exclusion criteria of the present study.

Definitions: Patients were defined hypertensive if systolic arterial pressure exceeded $140 \mathrm{mmHg}$ and/or diastolic arterial pressure exceeded 90 $\mathrm{mmHg}$, or had a history of use of antihypertensive drugs (18). Diabetes mellitus was defined whether patients with previous history of disease, use of diet, insulin or oral antidiabetic drugs, or had a fasting venous blood glucose level $\geq 126 \mathrm{mg} / \mathrm{dl}$ on two occasions in previously untreated patients. Hyperlipidemia was also defined as fasting total serum cholesterol >200 mg/dl, LDL >130 mg/dl, serum triglycerides $(\mathrm{TG})>180 \mathrm{mg} / \mathrm{dl}$, or the use of lipid-lowering drugs for a history of hypercholesterolemia (19). Height and weight of the study participants were recorded, and body mass index (BMI) was calculated as the weight divided by the square of height $(\mathrm{kg} / \mathrm{m} 2)$. Patients smoking 25 or more cigarettes daily at the time of diagnosis were recognized as active smokers.

Echocardiography: All study participants underwent comprehensive 2D, M-mode, conventional Doppler and color Doppler echocardiographic examinations to determine presence and severity of AS with a Vivid S5 (GE Vingmed, Horten, Norway) device using a 2.5- to $3.5-\mathrm{MHz}$ probe by an experienced cardiologist, who was unaware of study participants data. The aortic valve area (AVA) was calculated using the continuity equation. The maximum aortic gradient was calculated with continuous-wave Doppler ultrasound scan over the aortic valve according to the peak velocities, whereas the mean aortic gradient was calculated according to time-velocity integrals. The classification of AS severity was done based on the American College of Cardiology/American Heart Association guidelines for valvular heart disease as follows: 
(20): mild AS, AVA $<1.5 \mathrm{~cm} 2$, mean gradient $<25$ $\mathrm{mmHg}$, or jet velocity $<3.0 \mathrm{~m} / \mathrm{s}$; moderate AS, AVA $1.0-1.5 \mathrm{~cm} 2$, mean gradient $25-40 \mathrm{mmHg}$, or jet velocity $3.0-4.0 \mathrm{~m} / \mathrm{s}$; severe AS, AVA $<1.0$ $\mathrm{cm} 2$, mean gradient $>40 \mathrm{mmHg}$, or jet velocity $>4.0 \mathrm{~m} / \mathrm{s}$. Moreover, left ventricular ejection fraction (LVEF) was determined using Simpson's method of discs in two dimensional echocardiography (20).

Laboratory Measurements: Blood samples were drawn by vacuteiner into tubes containing EDTA as anticoagulant. Samples were collected from the antecubital vein between 08:00 and 10:00 AM following 12-h fasting period. Hematological parameters including platelet indices were obtained using the Coulter LH 780 Hematology Analyzer (Beckman Coulter Ireland, Inc., Mervue, Galway, Ireland). Moreover, the biochemical parameters, including fasting blood glucose, creatinine, lipid profiles were measured using an Abbott Diagnostics C8000i (Abbott, Germany) auto-analyzer with commercial kits.

Statistical Analysis: Continuous, normally distributed variables will be expressed as mean \pm standard deviation and non-normally distributed variables as median (interquartile range). Categorical variables will be expressed as frequencies and/or percentages. The variables will be investigated using visual (histograms, probability plots) and analytical methods (Kolmogorov-Smirnov) to determine if they are normally distributed. Kruskal-Wallis and MannWhitney U-tests were used for continuous nonnormally distributed variables, and one-way ANOVA and Tukey tests for continuous normally distributed variables. Categorical variables were compared by the likelihood ratio chi-square test. Correlations between variables were assessed using the Spearman rank correlations test. An overall 5\% type-I error level was used to infer statistical significance and a p-value less than 0.05 was considered significant. Two-sided p-values $<0.05$ were considered to be statistically significant. All statistical analyses were carried out using SPSS statistical software, version 21.0 (SPSS Inc., Chicago, Illinois, USA).

\section{Results}

Baseline demographic, clinical and laboratory characteristics of the AS and the control groups were summarized in Table 1 and Table 2. Patients with AS tended to be significantly younger than the control subjects are. Moreover, incidence of hyperlipidemia, systolic and diastolic blood pressure, fasting glucose were found to be significantly higher in the AS group than in the controls. When the two groups were compared in terms of hematologic parameters, PCT, PLR, mean platelet volume (MPV) and platelet counts were demonstrated to be significantly higher in patients with the AS. However, hemoglobin and lymphocyte counts were decreased in the AS group compared to the control group. Furthermore, as expected, maximum and mean transaortic gradients and peak jet blood velocity were found to be significantly higher in the AS patients compared to control subjects. Aortic valve area (AVA) was significantly lower in the AS group.

When the demographic, clinical and laboratory characteristics of the AS patients based on subdivisions were investigated (Table 3 and 4); age was highest in the severe AS group than in the other groups. Moreover, BMI, systolic blood pressure, creatinine were demonstrated to be significantly highest in the severe AS patients. However, LVEF was significantly lowered, as the severity of stenosis raised. When the hematologic parameters were evaluated in subdivisions of the

Table 1. Baseline demographic and clinical characteristics of the AS and the control groups

\begin{tabular}{lccc}
\hline & $\begin{array}{c}\text { Aortic Stenosis } \\
(\mathrm{n}=98)\end{array}$ & $\begin{array}{c}\text { Control } \\
(\mathrm{n}=30)\end{array}$ & $\mathrm{p}$ \\
\hline Age, y & $64.74 \pm 2.81$ & $66.17 \pm 3.11$ & $\mathbf{0 . 0 3 7}$ \\
Gender, M/F, n (\%) & $49 / 49(50 / 50)$ & $12 / 18(40 / 60)$ & 0.337 \\
BMI, kg/m2 & $27.72 \pm 0.96$ & $27.49 \pm 1$ & 0.506 \\
Smoking, n (\%) & $27(27.6)$ & $11(36.7)$ & 0.339 \\
Diabetes mellitus, n (\%) & $27(27.6)$ & $4(13.3)$ & 0.112 \\
Hypertension, n (\%) & $47(48)$ & $12(40)$ & 0.444 \\
Hyperlipidemia, n (\%) & $53(54.1)$ & $10(33.3)$ & $\mathbf{0 . 0 4 7}$ \\
SBP, mmHg & $132.85 \pm 5.87$ & $122.4 \pm 9.85$ & $<\mathbf{0 . 0 0 1 *}$ \\
DBP, mmHg & $80.86 \pm 3.86$ & $71.63 \pm 5.56$ & $<\mathbf{0 . 0 0 1 *}$ \\
\hline
\end{tabular}

AS: aortic stenosis; BMI: body mass index; DBP: diastolic blood pressure; SBP: systolic blood pressure. 
Table 2. Baseline laboratory and echocardiographic characteristics of the AS and the control groups

\begin{tabular}{|c|c|c|c|}
\hline & $\begin{array}{l}\text { Aortic Stenosis } \\
\quad(\mathrm{n}=98)\end{array}$ & $\begin{array}{l}\text { Control } \\
(\mathrm{n}=30) \\
\end{array}$ & $\mathrm{p}$ \\
\hline Glucose, $\mathrm{mg} / \mathrm{dL}$ & $99.07 \pm 26.62$ & $80.33 \pm 5.86$ & $<0.001 *$ \\
\hline Urea, mg/dL & $31.41 \pm 4.39$ & $30.57 \pm 3.45$ & 0.365 \\
\hline Creatinine, $\mathrm{mg} / \mathrm{dL}$ & $0.93 \pm 0.18$ & $0.82 \pm 0.17$ & $0.006 *$ \\
\hline $\mathrm{LDL}, \mathrm{mg} / \mathrm{dL}$ & $107.15 \pm 16.22$ & $110.63 \pm 13.43$ & 0.288 \\
\hline $\mathrm{HDL}, \mathrm{mg} / \mathrm{dL}$ & $46.96 \pm 4.8$ & $45.27 \pm 5.01$ & 0.097 \\
\hline $\mathrm{TG}, \mathrm{mg} / \mathrm{dL}$ & $133.69 \pm 36.8$ & $132.53 \pm 9.07$ & 0.865 \\
\hline Hemoglobin, g/dL & $12.08 \pm 0.95$ & $12.58 \pm 0.64$ & $<0.001 *$ \\
\hline Platelet, $\times 10^{3}$ & $232.98 \pm 28.67$ & $203.9 \pm 12.87$ & $<0.001 *$ \\
\hline $\mathrm{MPV}, \mathrm{fL}$ & $8.97 \pm 0.89$ & $8.46 \pm 0.54$ & $0.005^{*}$ \\
\hline Lymphocyte, $x 10^{3}$ & $1.87 \pm 0.14$ & $2.06 \pm 0.1$ & $<0.001 *$ \\
\hline PLR & $125.85 \pm 20.8$ & $99.13 \pm 8.18$ & $<0.001 *$ \\
\hline PCT & $0.21 \pm 0.04$ & $0.17 \pm 0.02$ & $<0.001 *$ \\
\hline LVEF, \% & $59.94 \pm 2.07$ & $60 \pm 2.69$ & 0.802 \\
\hline Maximal gradient, $\mathrm{mmHg}$ & $55.71 \pm 27.56$ & $7.57 \pm 1.33$ & $<0.001 *$ \\
\hline Mean gradient, $\mathrm{mmHg}$ & $31.4 \pm 16.26$ & $3.95 \pm 0.81$ & $<0.001 *$ \\
\hline Maximum jet velocity, $\mathrm{m} / \mathrm{s}$ & $3.29 \pm 1.28$ & $1.2 \pm 0.2$ & $<0.001 *$ \\
\hline Aortic valve area, $\mathrm{cm}^{2}$ & $1.31 \pm 0.44$ & $3.63 \pm 0.21$ & $<0.001 *$ \\
\hline
\end{tabular}

AS: aortic stenosis; HDL: high-density lipoprotein; LDL: low-density lipoprotein; LVEF: left ventricular ejection fraction; MPV: mean platelet volume; PCT: plateletcrit; PLR: Platelet to lymphocyte ratio; TG: triglyceride.

Table 3. Baseline demographic and clinical characteristics of the AS patients according to disease severity

\begin{tabular}{lcccc}
\hline & $\begin{array}{c}\text { Mild AS } \\
(\mathrm{n}=35)\end{array}$ & $\begin{array}{c}\text { Moderate AS } \\
(\mathrm{n}=30)\end{array}$ & $\begin{array}{c}\text { Severe AS } \\
(\mathrm{n}=33)\end{array}$ & $\mathrm{p}$ \\
\hline Age, y & $62.91 \pm 2.32$ & $64.87 \pm 2.46$ & $66.58 \pm 2.37$ & $\mathbf{0 . 0 0 1 *}$ \\
Gender, M, n (\%) & $18(51.4)$ & $16(53.3)$ & $15(45.5)$ & 0.805 \\
BMI, kg/m & $27.29 \pm 0.97$ & $27.76 \pm 0.96$ & $28.12 \pm 0.77$ & $\mathbf{0 . 0 0 4 *}$ \\
Smoking, n (\%) & $7(20)$ & $9(30)$ & $11(33.3)$ & 0.44 \\
Diabetes mellitus, n (\%) & $12(34.3)$ & $7(23.3)$ & $8(24.2)$ & 0.537 \\
Hypertension, n (\%) & $14(40)$ & $15(50)$ & $18(54.5)$ & 0.47 \\
Hyperlipidemia, n (\%) & $16(45.7)$ & $18(60)$ & $19(57.6)$ & 0.456 \\
SBP, mmHg & $131.63 \pm 4.78$ & $131.73 \pm 4.83$ & $135.15 \pm 7.11$ & $\mathbf{0 . 0 4 5 *}$ \\
DBP, mmHg & $80.46 \pm 3.32$ & $80.77 \pm 3.59$ & $81.36 \pm 4.62$ & 0.753 \\
\hline
\end{tabular}

AS: aortic stenosis; BMI: body mass index; DBP: diastolic blood pressure; SBP: systolic blood pressure.

AS; PCT, PLR, MPV and platelet counts were demonstrated to be significantly higher in the severe AS group than in the mild and moderate AS groups. However, lymphocyte counts were lowest in the AS group compared to in the others. The maximal and mean transaortic gradients, and maximum jet velocities were significantly increased, while the AVAs were significantly decreased, as the degree of stenosis increased.

Correlation analysis indicated (Table 5) positive significant relationships between the PCT and the maximal and mean transaortic gradients, and maximum jet velocities; and negative association with AVA. The same relations were obtained between PLR (Table 6) and echocardiographic parameters of severity of AS respectively (all $p$ values < 0.001). Furthermore, PCT, PLR, MPV and platelet counts were significantly directly correlated with themselves (all p values $<0.001$ ). MPV, as one of the new platelet indices, was positively correlated with the maximal $(r=0.592$, $\mathrm{p}<0.001)$ and mean transaortic gradients $(\mathrm{r}=$ $0.591, \mathrm{p}<0.001)$, and maximum jet velocities $(\mathrm{r}=$ $0.590, \mathrm{p}<0.001)$; and inversely correlated with AVA $(\mathrm{r}=-0.546, \mathrm{p}=0.001)$. Platelet count was also directly correlated with $\mathrm{MPV}(\mathrm{r}=0.320, \mathrm{p}<$ 0.001). 
Table 4. Baseline laboratory and echocardiographic characteristics of the AS patients according to disease severity

\begin{tabular}{|c|c|c|c|c|}
\hline & $\begin{array}{l}\text { Mild AS } \\
(\mathrm{n}=35)\end{array}$ & $\begin{array}{c}\text { Moderate AS } \\
\quad(\mathrm{n}=30)\end{array}$ & $\begin{array}{c}\text { Severe AS } \\
(\mathrm{n}=33)\end{array}$ & $\mathrm{p}$ \\
\hline Glucose, $\mathrm{mg} / \mathrm{dL}$ & $96.57 \pm 23.32$ & $98.23 \pm 23.38$ & $102.48 \pm 32.49$ & 0.583 \\
\hline Urea, mg/dL & $30.91 \pm 4$ & $31.1 \pm 3.38$ & $32.21 \pm 5.48$ & 0.683 \\
\hline Creatinine, $\mathrm{mg} / \mathrm{dL}$ & $0.9 \pm 0.18$ & $0.88 \pm 0.17$ & $1 \pm 0.18$ & $0.035 *$ \\
\hline $\mathrm{LDL}, \mathrm{mg} / \mathrm{dL}$ & $108.17 \pm 13.76$ & $105.9 \pm 15.08$ & $107.21 \pm 19.69$ & 0.856 \\
\hline HDL, mg/dL & $45.89 \pm 5.5$ & $47.97 \pm 3.37$ & $47.18 \pm 5.01$ & 0.209 \\
\hline $\mathrm{TG}, \mathrm{mg} / \mathrm{dL}$ & $131.17 \pm 40.94$ & $134.37 \pm 40.92$ & $135.76 \pm 28.21$ & 0.872 \\
\hline Hemoglobin, g/dL & $12.16 \pm 1.04$ & $12.09 \pm 0.92$ & $11.98 \pm 0.88$ & 0.966 \\
\hline Platelet, $\times 10^{3}$ & $216.97 \pm 18.2$ & $225.6 \pm 21.98$ & $256.67 \pm 28.14$ & $<0.001 *$ \\
\hline $\mathrm{MPV}, \mathrm{fL}$ & $8.47 \pm 0.42$ & $8.64 \pm 0.61$ & $9.81 \pm 0.9$ & $<0.001 *$ \\
\hline Lymphocyte, x103 & $1.92 \pm 0.08$ & $1.91 \pm 0.13$ & $1.77 \pm 0.15$ & $<0.001 *$ \\
\hline PLR & $112.97 \pm 8.99$ & $118.54 \pm 13.88$ & $146.16 \pm 19.84$ & $<0.001 *$ \\
\hline PCT & $0.18 \pm 0.02$ & $0.19 \pm 0.02$ & $0.25 \pm 0.04$ & $<0.001 *$ \\
\hline LVEF, \% & $60.29 \pm 1.62$ & $60.8 \pm 2.11$ & $58.79 \pm 2$ & $<0.001 *$ \\
\hline Maximal gradient, $\mathrm{mmHg}$ & $28.06 \pm 3.96$ & $49.37 \pm 3.59$ & $90.82 \pm 11.38$ & $<0.001 *$ \\
\hline Mean gradient, mmHg & $14.23 \pm 2.17$ & $28.77 \pm 1.91$ & $52 \pm 5.11$ & $<0.001 *$ \\
\hline Maximum jet velocity, $\mathrm{m} / \mathrm{s}$ & $1.82 \pm 0.48$ & $3.43 \pm 0.25$ & $4.71 \pm 0.43$ & $<0.001 *$ \\
\hline Aortic valve area, $\mathrm{cm}^{2}$ & $1.83 \pm 0.11$ & $1.26 \pm 0.04$ & $0.80 \pm 0.10$ & $<0.001 *$ \\
\hline
\end{tabular}

AS: aortic stenosis; HDL: high-density lipoprotein; LDL: low-density lipoprotein; LVEF: left ventricular ejection fraction; MPV: mean platelet volume; PCT: plateletcrit; PLR: Platelet to lymphocyte ratio; TG: triglyceride.

Table 5. Correlation analysis between PCT and study variables in patients with the AS

\begin{tabular}{lcc}
\hline & $\mathrm{r}$ & $\mathrm{P}$ \\
\hline PLR & 0.805 & $\mathbf{< 0 . 0 0 1}$ \\
MPV & 0.691 & $<\mathbf{0 . 0 0 1}$ \\
Platelet count & 0.865 & $\mathbf{<} \mathbf{0 . 0 0 1}$ \\
Aort $_{\text {max }}$ & 0.677 & $\mathbf{0 . 0 0 1}$ \\
Aort $_{\text {mean }}$ & 0.679 & $<\mathbf{0 . 0 0 1}$ \\
Aort $_{\text {maxjet }}$ & 0.678 & $<\mathbf{0 . 0 0 1}$ \\
AVA & -0.620 & $<\mathbf{0 . 0 0 1}$ \\
\hline
\end{tabular}

AVA: aortic valve area; Aort $_{\text {max }}$ : maximum transaortic gradient; Aort $_{\text {mean }}$ : mean transaortic gradient; Aort maxjet: : maximum jet blood flow; MPV: mean platelet volume; PCT: plateletcrit; PLR: platelet to lymphocyte ratio.

\section{Discussion}

We reported that increased PCT and PLR are related to presence and severity of the calcific AS. This is the first study to demonstrate a strong significant relationship between PCT and severity of the AS. Moreover, PCT and PLR were found to be significantly correlated with other platelet indices such as mean platelet volume and platelet
Table 6. Correlation analysis between PLR and study variables in patients with the AS

\begin{tabular}{lcc}
\hline & $\mathrm{r}$ & $\mathrm{p}$ \\
\hline PCT & 0.805 & $<\mathbf{0 . 0 0 1}$ \\
MPV & 0.411 & $<\mathbf{0 . 0 0 1}$ \\
Platelet count & 0.874 & $<\mathbf{0 . 0 0 1}$ \\
Aort $_{\text {max }}$ & 0.633 & $<\mathbf{0 . 0 0 1}$ \\
Aort $_{\text {mean }}$ & 0.650 & $<\mathbf{0 . 0 0 1}$ \\
Aort $_{\text {maxjet }}$ & 0.661 & $<\mathbf{0 . 0 0 1}$ \\
AVA & -0.595 & $<\mathbf{0 . 0 0 1}$ \\
\hline
\end{tabular}

AVA: aortic valve area; Aortmax: maximum transaortic gradient; Aortmean: mean transaortic gradient; Aortmaxjet: maximum jet blood flow; MPV: mean platelet volume; PLR: platelet to lymphocyte ratio.

count. These results suggest that increased PCT and PLR have an impact on both prothrombotic and proinflammatory states.

The calcific AS and atherosclerosis share similar etiologies and pathophysiologic mechanisms, which are composed of chronic inflammation, endothelial damage, mechanical shear stress, deposition and oxidization of lipid-rich particles at vulnerable plaque sites, neoangiogenesis resulting 
calcification (21). Platelets participate actively in the process of inflammation, atherogenesis and thrombus formation via production and release of several cytokines and chemokines, which are crucial mediators of vascular wall inflammation and shear stress (22). Severe chronic inflammation triggers megakaryocytic proliferation and lead to relative thrombocytosis (22). Platelets also have an important role in the transmigration of leukocytes, monocytes and macrophages into the sites of inflammation and vascular injury, which are significant pathophysiological pathways for developing of the calcific AS $(21,22)$. An increased platelet reactivity, hyperaggregability and thrombus formation in the setting of the calcific AS was demonstrated in previous study (23). Prohaska et al. (4) reported a pre-operative marked platelet dysfunction in patients underwent isolated coronary artery bypass surgery and single aortic valve replacement. They suggested that platelets, after an initial activation due to impaired blood flow and shear stress, might participate in microvascular dysfunction and thrombotic events in the AS.

PCT indicates the number of circulating platelets in a unit volume of blood, which is analogous to the haematocrit for erythrocytes (24). It has been evaluated as a novel predictor of severe inflammation and raised cardiovascular risk. A clinical utility of PCT in predicting a slow coronary flow phenomenon was demonstrated in the study of Akpinar et al. (10). Moreover, a positive direct relation between PCT and critical saphenous vein graft stenosis was found in a recent study (11). Ugur et al. (8) reported that admission PCT was a significant independent predictor for long-term cardiovascular mortality in patients undergoing primary angioplasty for STEMI. The similar considerable prognostic value of PCT was reported in NSTEMI by the study of Gul et al. (6). Furthermore, Oylumlu et al. (9) demonstrated an increased mean PCT value in the cardiac syndrome $\mathrm{X}$ (CSX) patients and it was presented as a significant predictor of presence of the CSX with normal coronary arteries. In our study, PCT was found to be raised in the calcific AS patients, which was associated with severity of disease. It also directly correlated with other platelet indices such as PLR and MPV. It can be suggested that, raised PCT levels may due to severe chronic inflammation and increased platelet activity and aggregability, which play roles in the pathogenesis of the AS.

PLR, which is an indicator of increased inflammation, platelet activation and aggregation, combines the risk predictor effect of two parameters into a single risk factor (13). Previous clinical studies demonstrated a significant independent value of PLR in predicting long term major adverse outcomes in various cardiovascular diseases (12-17). Akdag et al. (17) reported that PLR was significantly higher in severe and mildto-moderate AS groups when compared to the control subjects. Moreover, it was found to be higher in the severe AS group compared to mildto-moderate group in subgroup analysis of the study. PLR was found to be significantly correlated with echocardiographic parameters of severity of AS. In our study, concordant with the Akdag et al. (17) study, similar findings were found in terms of relation between PLR and presence and severity of the AS. Kurtul et al. (14) demonstrated that elevated PLR was related with both severity and complexity of coronary artery disease and had an important prognostic value for in-hospital mortality in the setting of acute coronary syndrome. Temiz et al. (25) also reported a considerable prognostic significance of PLR for early cardiovascular mortality in STEMI.

The possible theory for these findings may be an increased blood viscosity and thrombus formation due to exaggerated platelet activity and aggregability resulting in increased PCT and PLR. Chronic inflammation, endothelial dysfunction and oxidative processes, which are seen both in the atherosclerosis and calcific AS, further increases platelet functions and responses causing severe form of disease. Turbulent jet blood flow and increased shear stress, occurred in the setting of calcific AS, may destruct endothelium of vascular wall around or near aortic valves and may trigger an increase of platelet activation, aggregation and coagulation cascade results in raised PCT and PLR values.

Study Limitations: The present study has some limitations. First, this is a single center and retrospective study, which has not data about future major adverse cardiovascular events of patients to determine prognostic significance of PCT and PLR in this setting. Second, because of single measurement of PLR and PCT on admission, serial changes in response to medical or interventional treatment could not be evaluated. Third, although this study has a relatively small sample size, we were able to demonstrate strong relationship between PCT, PLR and presence and severity of AS respectively. A lack of data about levels of specific markers for oxidative stress, inflammation and endothelial 
dysfunction was the last limitation of the present study.

We demonstrated, for the first time, a strong significant relation between PCT and presence and severity of AS in our study. Moreover, similar findings were presented for PLR in patients with calcific AS. PCT and PLR, which are part of routine complete blood count and reflect elevated inflammatory status and platelet activation and aggregation, are useful, cheap, easily available and simply calculated markers that have an ability to improve risk stratification of patients with calcific AS for treatment strategies. Further studies with prospective design and larger population size are needed to elucidate precise relationship between the new platelet indices and presence and severity of the AS.

Decleration of Conflicting Interests: The author(s) declared no potential conflicts of interest with respect to the research, authorship, and/or publication of the present article.

Funding: The author(s) received no financial support for the research, authorship and/or publication of the present article.

\section{References}

1. Tziomalos K, Athyros VG, Karagiannis A, Mikhailidis DP. Established and emerging vascular risk factors and the development of aortic stenosis: An opportunity for prevention? Expert Opin Ther Targets 2008; 12(7): 809-820.

2. Rajamannan NM, Evans FJ, Aikawa E, GrandeAllen KJ, Demer LL, Heistad DD, et al. Calcific aortic valve disease: Not simply a degenerative process: A review and agenda for research from the National Heart and Lung and Blood Institute Aortic Stenosis Working Group. Executive summary: Calcific aortic valve disease - 2011 update. Circulation 2011; 124(16): 1783-1791.

3. Holme PA, Orvim U, Hamers MJ, Solum NO, Brosstad FR, Barstad RM, et al. Shear-induced platelet activation and platelet microparticle formation at blood flow conditions as in arteries with a severe stenosis. Arterioscler Thromb Vasc Biol 1997; 17(4): 646-653.

4. Prohaska W, Zittermann A, Lüth JU, Inoue K, Köster-Eiserfunke W, Baller D, et al. Prevalent platelet dysfunction in patients with aortic valve disease. J Heart Valve Dis 2008; 17(5): 542-547.

5. Fazio G, Caracciolo C, Barone R, D'angelo L, Di Maggio R, Vernuccio F, et al. An unknown cause of aortic valve stenosis: polycythemia vera. J Thromb Thrombolysis 2013; 35(2): 282-285.

6. Gul M, Uyarel H, Akgul O, Akkaya E, Surgit O, Cakmak HA, et al. Long-term prognostic significance of admission plateletcrit values in patients with non-ST elevation myocardial infarction. Blood Coagul Fibrinolysis 2016. Article In Press.

7. Akin F, Ayca B, Kose N, Altun I, Avsar M, Celik $\mathrm{O}$, et al. Relation of platelet indices to severity of coronary artery disease in patients undergoing primary percutaneous coronary intervention. Perfusion 2015. pii: 0267659115594231. Article In Press.

8. Uğur M, Ayhan E, Bozbay M, Çiçek G, Ergelen $\mathrm{M}$, Issı $\mathrm{T}$, et al. The independent association of plateletcrit with long-term outcomes in patients undergoing primary percutaneous coronary intervention. J Crit Care 2014; 29(6): 978-981.

9. Oylumlu M, Oylumlu M, Yuksel M, Dogan A, Cakici M, Ozgeyik M, et al. The usefulness of plateletcrit to predict cardiac syndrome $\mathrm{X}$ in patients with normal coronary angiogram. Postepy Kardiol Interwencyjnej 2015; 11(3): 197201.

10. Akpinar I, Sayin MR, Gursoy YC, Aktop Z, Karabag T, Kucuk E, et al. Plateletcrit and red cell distribution width are independent predictors of the slow coronary flow phenomenon. J Cardiol 2014; 63(2): 112-118.

11. Akpinar I, Sayin MR, Gursoy YC, Karabag T, Kucuk E, Buyukuysal MC, et al. Plateletcrit: a platelet marker associated with saphenous vein graft disease. Herz 2014; 39(1): 142-148.

12. Kurtul A, Yarlioglues M, Murat SN, Ergun G, Duran M, Kasapkara HA, et al. Usefulness of the platelet-to-lymphocyte ratio in predicting angiographic reflow after primary percutaneous coronary intervention in patients with acute STsegment elevation myocardial infarction. Am J Cardiol 2014; 114(3): 342-347.

13. Taşoğlu I, Sert D, Colak N, Uzun A, Songur M, Ecevit A. Neutrophil-Lymphocyte Ratio and the Platelet-Lymphocyte Ratio Predict the Limb Survival in Critical Limb Ischemia. Clin Appl Thromb Hemost 2013; 20(6): 645-650.

14. Kurtul A, Murat SN, Yarlioglues M, Duran M, Ergun G, Acikgoz SK, et al. Association of Platelet-to-Lymphocyte Ratio with Severity and Complexity of Coronary Artery Disease in Patients with Acute Coronary Syndromes. Am J Cardiol 2014; 114(7): 972-978.

15. Oylumlu M, Doğan A, Oylumlu M, Yildız A, Yüksel M, Kayan F, et al. Relationship between platelet-to-lymphocyte ratio and coronary slow flow. Anatol J Cardiol 2015; 15(5): 391-395.

16. Açar G, Kalkan ME, Avci A, Alizade E, Tabakci MM, Toprak C, et al. The relation of plateletlymphocyte ratio and coronary collateral circulation in patients with stable angina pectoris and chronic total occlusion. Clin Appl Thromb Hemost 2015; 21(5): 462-468. 
17. Akdag S, Akyol A, Asker M, Duz R, Gumrukcuoglu HA. Platelet-to-Lymphocyte Ratio May Predict the Severity of Calcific Aortic Stenosis. Med Sci Monit 2015; 21: 3395-3400.

18. James PA, Oparil S, Carter BL, Cushman WC, Dennison-Himmelfarb C, Handler J, et al. 2014 evidence-based guideline for the management of high blood pressure in adults: report from the panel members appointed to the Eighth Joint National Committee (JNC 8). JAMA 2014; 311(5): 507-520.

19. European Association for Cardiovascular Prevention \& Rehabilitation, Reiner Z, Catapano AL, De Backer G, Graham I, Taskinen MR, Wiklund O, et al. ESC Committee for Practice Guidelines (CPG) 2008-2010 and 2010-2012 Committees. ESC/EAS Guidelines for the management of dyslipidaemias: the Task Force for the management of dyslipidaemias of the European Society of Cardiology (ESC) and the European Atherosclerosis Society (EAS). Eur Heart J 2011; 32(14): 1769-1818.

20. Lang RM, Badano LP, Mor-Avi V, Afilalo J, Armstrong A, Ernande L, et al. Recommendations for cardiac chamber quantification by echocardiography in adults: an update from the American Society of Echocardiography and the European Association of Cardiovascular Imaging. Eur Heart J Cardiovasc Imaging 2015; 16(3): 233-270.

21. Freeman RV, Otto CM. Spectrum of calcific aortic valve disease: Pathogenesis, disease progression, and treatment strategies. Circulation 2005; 111(24): 3316-3326.

22. Langer HF, Gawaz M. Platelet-vessel wall interactions in atherosclerotic disease. Thromb Haemost 2008; 99(3): 480-486.

23. Stein PD, Sabbah HN, Pitha JV. Continuing disease process of calcific aortic stenosis. Role of microthrombi and turbulent flow. Am J Cardiol 1977; 39(2): 159-163.

24. Ergelen M, Uyarel H. Plateletcrit: a novel prognostic marker for acute coronary syndrome. Int J Cardiol 2014; 177(1): 161.

25. Temiz A, Gazi E, Güngör Ö, Barutçu A, Altun B, Bekler A, et al. Platelet/lymphocyte ratio and risk of in-hospital mortality in patients with STelevated myocardial infarction. Med Sci Monit 2014; 20: 660-665. 